\title{
Antioxidant properties of fullerenol-d
}

\author{
D. P. Tyurin ${ }^{1}$, F. S. Kolmogorov ${ }^{1}$, I. A. Cherepkova ${ }^{1}$, N. A. Charykov ${ }^{1,5}$, K. N. Semenov ${ }^{1,2}$, V. A. Keskinov ${ }^{1}$, \\ N. M. Safyannikov ${ }^{5}$, Yu. V. Pukharenko ${ }^{3}$, D. G. Letenko ${ }^{3}$, T. A. Segeda ${ }^{4}$, Z. Shaimardanov ${ }^{4}$ \\ ${ }^{1}$ St. Petersburg State Technological Institute (Technical University), \\ Moskovsky prospect, 26, Saint Petersburg, 190013, Russia \\ ${ }^{2}$ St. Petersburg State University, 7/9 Universitetskaya emb., Saint Petersburg, 199034, Russia \\ ${ }^{3}$ St.Petersburg State University of Architecture and Civil Engineering (SPSUACE), \\ 2nd Krasnoarmeiskaya St. 4, 190005, Saint Petersburg, Russia \\ ${ }^{4}$ D. Serikbayev East Kazakhstan state technical university, \\ A. K. Protozanov Street, 69, Ust-Kamenogorsk city, 070004, The Republic of Kazakhstan \\ ${ }^{5}$ St. Petersburg Electrotechnical University "LETI", \\ ul. Professora Popova 5, 197376, Saint Petersburg, Russia \\ keskinov@mail.ru
}

PACS 61.48.+c

DOI 10.17586/2220-8054-2018-9-6-798-810

\begin{abstract}
Fullerenol-d $\mathrm{C}_{60}(\mathrm{OH})_{22-24}$ was synthesized by the method of direct heterogeneous oxidation of fullerene $\mathrm{C}_{60}$, dissolved in o-xylene, by NaOH, dissolved in water, in the presence of interphase catalyst $\left[t-\left(\mathrm{C}_{4} \mathrm{H}_{9}\right)_{4} \mathrm{~N}\right] \mathrm{OH}$. Identification of fullerenol-d was provided by: C-H-N elemental analysis, High performance liquid phase chromatography, IR - and Electronic spectroscopy, Mass-spectrometry. The antioxidant properties of aqueous fullerenol-d solutions were investigated against free radicals, generated by hydrogen peroxide and molecular $\mathrm{I}_{2}$. Measurement of fullerenol antioxidant activity was based on the potentiometric titration of fullerenol solutions by hydrogen peroxide and molecular $\mathrm{I}_{2}$ solutions and vice versa with compact Pt as working electrode. As a comparison, the very popular and strong anti-oxidant - ascorbic acid was used. Pourbaix Diagrams $(p H-E h)$ for hydrogen-oxygen and iodine forms were constructed. Fullerenol-d is a weaker antioxidant than ascorbic acid, but in contrast, fullerenols-d molecules are able to undergo multiply reversible absorption-desorption of some free radicals.
\end{abstract}

Keywords: fullerenol, antioxidant properties, hydrogen peroxide, iodine, Pourbaix Diagrams, platinum electrode.

Received: 19 July 2018

Revised: 12 November 2018

Final revision: 21 November 2018

\section{Introduction}

This research continues the series of reports, concerning synthesis, identification and investigation of the properties of polyhydroxylated derivatives (also named as fullerenols) of light fullerenes $\mathrm{C}_{60}$ and $\mathrm{C}_{70}$ (see, for example [1-28]).

Antioxidant properties of fullerenols were previously investigated [7,9,17,42-50]. Several mechanisms for the antioxidant activity of fullerenol nanoparticles have been proposed [42]. The possible mechanism of the antioxidative activity of fullerenol $\mathrm{C}_{60}(\mathrm{OH})_{24}$ is the radical-addition reaction of $2 n\left(\mathrm{OH}^{*}\right)$ (here and further $\left(\mathrm{R}^{*}\right)$ is free radical with one free electron) radicals to the remaining olefinic double bonds of the fullerenol core to yield $\left[\mathrm{C}_{60}(\mathrm{OH})_{24}\right]\left(\mathrm{OH}^{*}\right)_{2 n}$. The other proposed mechanism is the possibility of a hydroxyl radical to abstract a hydrogen from fullerenol, including the formation of a relatively stable fullerenol radical $\left[\mathrm{C}_{60}(\mathrm{OH})_{23}\right]\left(\mathrm{O}^{*}\right)[46]$. In addition, a hydroxyl radical may abstract one electron from fullerenol yielding the radical cation $\left[\mathrm{C}_{60}(\mathrm{OH})_{24}\right]^{+}$. One more proposed mechanism is that the polyanion nanoparticles have numerous free electron pairs from oxygen, distributed around the fullerenol molecules, and have a great capacity to form coordinative bonds with prooxidant metal ions [9]. The obtained result demonstrated that fullerenol decreased the reduction of cytochrome-C for $5-$ 40 rel. \% [7]. The hypothetical mechanism of action of the polyanion fullerenol $\mathrm{C}_{60}(\mathrm{OH})_{24}$ with the superoxide radical anion is presented in [50]. Some results suggest that $\mathrm{C}_{60}(\mathrm{OH})_{32} \cdot 8 \mathrm{H}_{2} \mathrm{O}$ scavenges $\left(\mathrm{OH}^{*}\right)$ owing to the dehydrogenation of $\mathrm{C}_{60}(\mathrm{OH})_{32} \cdot 8 \mathrm{H}_{2} \mathrm{O}$ and is simultaneously oxidized to a stable fullerenol radical [47]. The antioxidant ability of $\mathrm{C}_{60}(\mathrm{OH})_{32} \cdot 8 \mathrm{H}_{2} \mathrm{O}$ was also confirmed in a beta-carotene bleaching assay [48]. The results suggest that fullerennols possess NO-scavenging activity in vivo [7]. The scavenger activity of fullerenol with a smaller or moderate number of hydroxyl groups with $\left(\mathrm{OH}^{*}\right)$ radicals can be explained by addition to $\mathrm{sp}^{2}$ carbon atoms $[46,49]$. 
The phototoxic antioxidant properties of fullerenols have also been reported $[42,51,52]$. Fullerenol $\mathrm{C}_{60}(\mathrm{OH})_{24}$ produces a mixture of reactive oxygen species under both visible and ultraviolet irradiation through two types of photochemical mechanisms [51], with the greatest rates of oxygen consumption at acidic $p H(p H=5)$. Evidence of both singlet oxygen $\left({ }^{1} \mathrm{O}_{2}\right)$ and superoxide radical ion production $\left(\mathrm{O}_{2}^{*}\right)^{-}$was obtained and when compared to other known sensitizers of reactive oxygen; fullerenol $\mathrm{C}_{60}(\mathrm{OH})_{24}$ produced higher quantities of active oxygen species at a rate at least two times that of other sensitizers [52]. Comparing phototoxicity toward $\mathrm{HaCaT}$ of $\left(\gamma-\mathrm{C}_{y} \mathrm{D}\right)_{2} / \mathrm{C}_{60}(\mathrm{c}-$ cyclodextrin bicapped $\mathrm{C}_{60}$ ) and fullerenol, Zhao et al. concluded that fullerenol was less phototoxic [53].

\section{Pourbaix diagram}

A Pourbaix diagram (diagram of predominant forms, $E h-p H$ diagram) is one that illustrates thermodynamically stable forms of existence of elements (ions, molecules, atomic crystals and metals) in solutions at different values of hydrogen indicator $-p H$ and redox electrode potential for compact Pt electrode - Eh [54,55]. These diagrams were proposed by Marcel Pourbaix [54]. For each element, you can build a separate Pourbaix diagram. Pourbaix diagrams for one element may vary depending on temperature, solvent and presence of ligands in solution. But, as a rule, Pourbaix diagrams are for aqueous solutions at the temperatures near $25{ }^{\circ} \mathrm{C}$. Pourbaix diagrams are constructed on the basis of the Nernst equation and the standard redox potentials.

The Pourbaix diagram is constructed in coordinates of $E h$ (ordinate) $-p H$ (abscissa). It reflects the species that are thermodynamically stable at a given $p H$ value and the oxidation-reduction potential of the medium - Eh. At a lower potential, the corresponding form can be reduced to the underlying (if any), at a higher - oxidized to the overlying (if any). The boundaries between the existing species of a solution-solid or solution-gas usually depend on the concentration of dissolved forms; the boundaries between the existing species of dissolved forms, as a rule, do not depend on their concentration. Often, the Pourbaix diagram is applied to the boundary of the region of existence of water. The upper of them $(E h=1.23-0.059 \mathrm{pH})$ corresponds to the release of oxygen (that is, at higher potentials it is possible to oxidize water to oxygen):

$$
\begin{aligned}
4 \mathrm{H}_{2} \mathrm{O}-4 e^{-} & =4 \mathrm{H}^{+}+\mathrm{O}_{2} \quad(p H<7), \\
4 \mathrm{OH}^{-}-4 e^{-} & =2 \mathrm{H}_{2} \mathrm{O}+\mathrm{O}_{2} \quad(p H>7) .
\end{aligned}
$$

The lower limit $(E h=-0.059 p H)$ corresponds to the release of hydrogen (that is, at lower potentials it is possible to recover water to hydrogen):

$$
\begin{gathered}
2 \mathrm{H}^{+}+2 e^{-}=\mathrm{H}_{2} \quad(p H<7), \\
2 \mathrm{H}_{2} \mathrm{O}+2 e^{-}=\mathrm{H}_{2}+2 \mathrm{OH}^{-} \quad(p H>7) .
\end{gathered}
$$

The Pourbaix diagram $[53,54]$ is one of the most powerful means of predicting the direction of chemical reactions of compounds of this element. From this, it is possible to determine the conditions of most acid-base and redox reactions of compounds of this element without taking into account the interaction with different ions. It is possible to predict the processes of disproportionation and non-proportionally different forms, whether they can contribute hydrogen and oxygen. By comparing the Pourbaix diagrams for the two elements, it is possible to predict the redox reactions between their compounds.

\section{Experimental section}

\subsection{Fullerenol-d synthesis and identification}

For synthesis, the authors used fullerene $\mathrm{C}_{60}$, produced by ILIP Corporation (S-Petersburg, Russia) with the purity 99.5 mass. \%. All other reactants had qualification "pure for the analysis".

Fullerenol-d $\mathrm{C}_{60}(\mathrm{OH})_{22-24}$ was synthesized by the method of direct heterogeneous oxidation of fullerene $\mathrm{C}_{60}$, dissolved in o-xylene, by $\mathrm{NaOH}$, dissolved in water, in the presence of interphase catalyst $\left[t-\left(\mathrm{C}_{4} \mathrm{H}_{9}\right)_{4} \mathrm{~N}\right] \mathrm{OH}$ (see, for example [27-29,42]). The following synthesis reactions were realized:

$$
\begin{gathered}
\mathrm{C}_{60} \mid(\text { o-xylene })+(22-24) \mathrm{NaOH}(\text { water })+\left[t-\left(\mathrm{C}_{4} \mathrm{H}_{9}\right)_{4} \mathrm{~N}\right] \mathrm{OH}(\text { interphase }) \rightarrow \\
\mathrm{C}_{60}(\mathrm{ONa})_{22-24}(\text { water })+(11-12) \mathrm{H}_{2} ; \\
\mathrm{C}_{60}(\mathrm{ONa})_{22-24}+(22-24) \mathrm{HCl} \rightarrow \mathrm{C}_{60}(\mathrm{OH})_{22-24}+(22-24) \mathrm{NaCl}\left(\mathrm{CH}_{3} \mathrm{OH}-\text { solution }\right) .
\end{gathered}
$$

Reaction was provided for 7 days; the aqueous phase was separated from the organic phase; product (fullerenol-d) was salting-out by methanol and then purified by triple recrystallization (methanol-water) [27-29,42]. Identification of fullerenol-d was provided by: $\mathrm{C}-\mathrm{H}-\mathrm{N}$ element analysis, High performance liquid phase chromatography 
(HPLC) - device chromatograph "Shimadzu Europa GmbH", IR - and Electronic spectroscopy, devices: IRAffinity1S and UV-1280, Mass-spectrometry, device - Bruker MS [27-29]. In particular, with the help of mass-spectrum we determined the number of hydroxyl groups (22-24), purity was determined by HPLC (98.5 mass \%).

\subsection{Antioxidant properties investigation}

To investigate antioxidant properties of ascorbic acid and fullerenol (against oxidants: hydrogen per-oxide and iodine) we determined redox potential $E h$ at fixed value of hydrogen indicator $p H=4.77$, which was set by acetate buffer solution $\mathrm{CH}_{3} \mathrm{COOH} / \mathrm{CH}_{3} \mathrm{COONa}$ (molar relation 1/1). We used electrochemical cells, containing two electrodes: $\mathrm{Pt}$ (compact) is working electrode; $\mathrm{Hg}, \mathrm{Hg}_{2} \mathrm{Cl}_{2} / \mathrm{KCl}\left(1 \mathrm{~mole} / \mathrm{dm}^{3}\right)$ - reference normal calomel electrode with constant potential and investigated solution in acetate buffer solution. Device pH-meter "ATC pH 200" was used as a Voltmeter during potential-metric titration of anti-oxidants by oxidants and vice-versa.

Titration of comparative "standard" antioxidant - ascorbic acid by hydrogen peroxide and molecular $\mathrm{I}_{2}$ and vice versa.

\subsection{Hydrogen peroxide titration}

It is well known, that in an aqueous solution of comparative "standard" antioxidant - ascorbic acid, may realize oxidation-reduction equilibrium between ascorbic acid (reduced form) and dehydroascorbic acid (oxidized form). It is only the first step of oxidation [56,57] by hydrogen peroxide (eq. 3.1) or $\mathrm{I}_{2}$ in KI water solution (eq. 3.2):
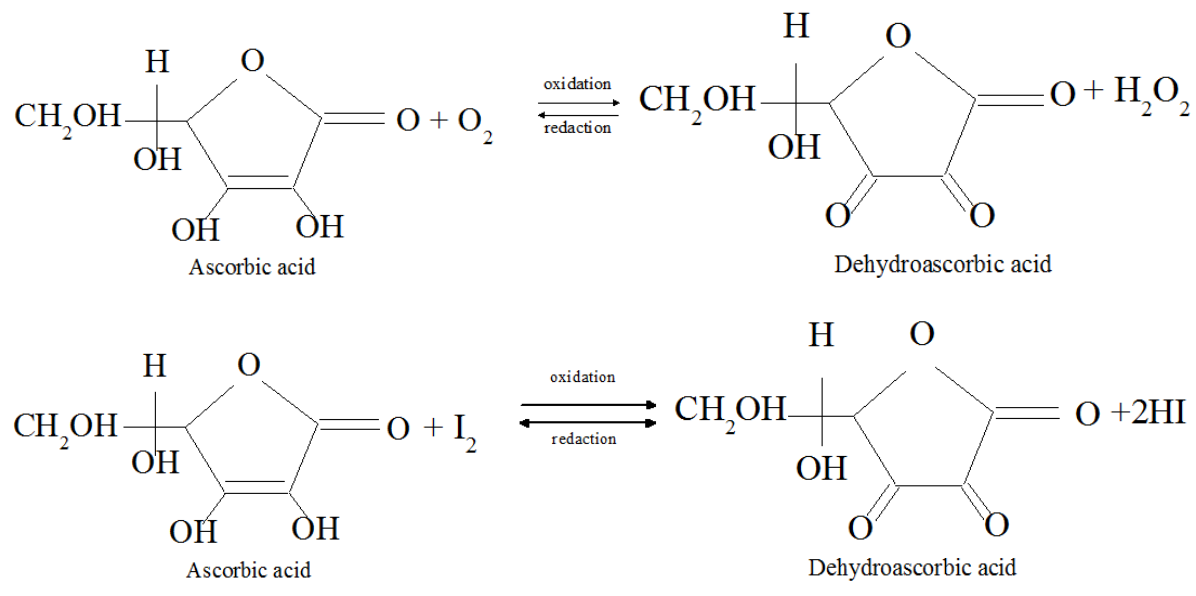

We used following electrochemical cells:

$$
\mathrm{Hg}, \mathrm{Hg}_{2} \mathrm{Cl}_{2} / \mathrm{KCl}\left(1 \mathrm{~mole} / \mathrm{dm}^{3}\right) / \text { investigated solution/Pt (compact), }
$$

where: $\mathrm{Pt}$ (compact) is working electrode; $\mathrm{Hg}, \mathrm{Hg}_{2} \mathrm{Cl}_{2} / \mathrm{KCl}\left(1 \mathrm{~mole} / \mathrm{dm}^{3}\right)$ - reference normal calomel electrode with constant potential $E^{0}=0.281 \mathrm{~V}$ [58]. Investigated solution in had two compositions:

$$
\begin{aligned}
& \text { ascorbic acid + dehydroascorbic acid }+\mathrm{H}_{2} \mathrm{O}_{2}+\mathrm{O}_{2}+\mathrm{H}^{+} \text {(acetate buffer); } \\
& \text { /ascorbic acid + dehydroascorbic acid }+\mathrm{I}_{2}+\mathrm{I}^{-}(\mathrm{KI})+\mathrm{H}^{+} \text {(acetate buffer). }
\end{aligned}
$$

The integral and differential curves of the titration of $\mathrm{H}_{2} \mathrm{O}_{2}$ by ascorbic acid and vice-versa ascorbic acid by $\mathrm{H}_{2} \mathrm{O}_{2}$ are represented in Fig. 1(a-d).

One can see absolutely equivalent quantities of ascorbic acid and hydrogen peroxide, according to eq. 3.1 and $\mathrm{I}_{2}$, according to eq. 3.2.

One can also see that upper plateau in two curves $E_{1} \approx 0.32 V$ (Fig. 1(a,c)) corresponds to the following electrode semi-reaction:

$$
\mathrm{O}_{2}+2 \mathrm{H}^{+\cdot}+2 \bar{e} \rightarrow \mathrm{H}_{2} \mathrm{O}_{2}(\mathrm{Pt})
$$

upper plateau in two curves $E_{2} \approx 0.34 V$ (Fig. $2(\mathrm{a}, \mathrm{c})$ ) corresponds to the following electrode semi-reaction:

$$
\mathrm{I}_{2} \text { (liquid) }+2 e \rightarrow 2 \mathrm{I}^{-}(\mathrm{Pt}),
$$

bottom plateau in four curves $E_{3} \approx 0.03 V$ (Figs. $\left.1(\mathrm{a}, \mathrm{c}), 2(\mathrm{a}, \mathrm{c})\right)$ corresponds to the same electrode semi-reaction: 


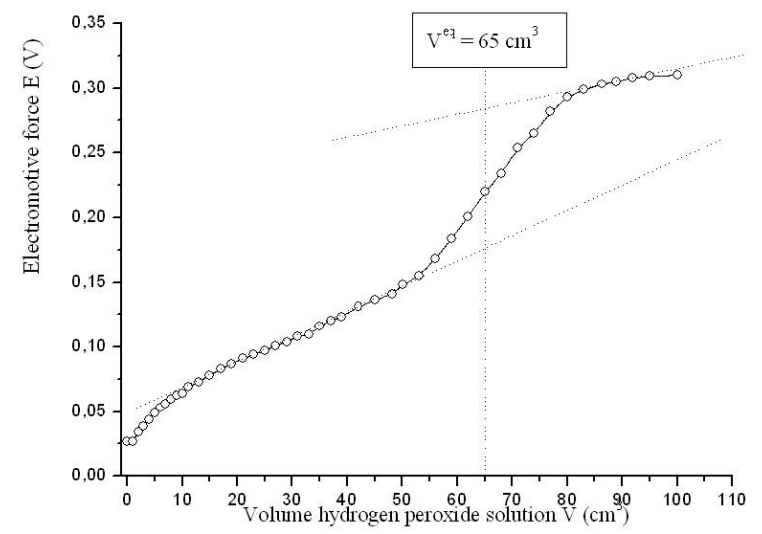

(a)

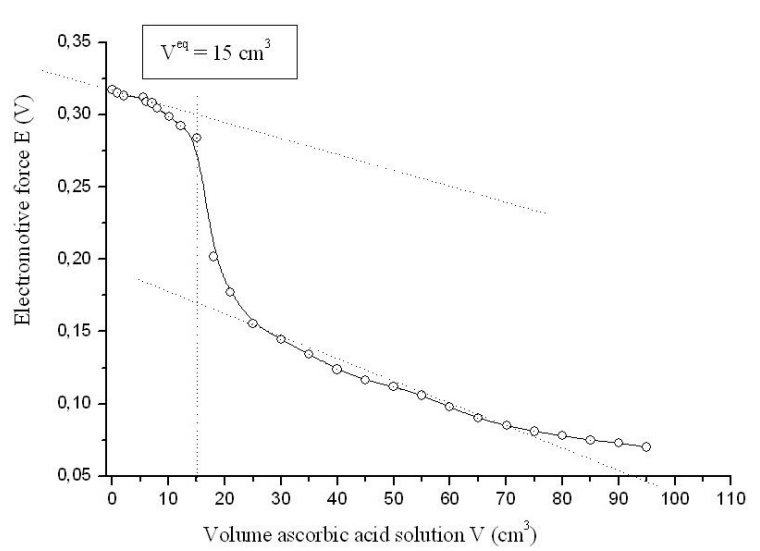

(c)

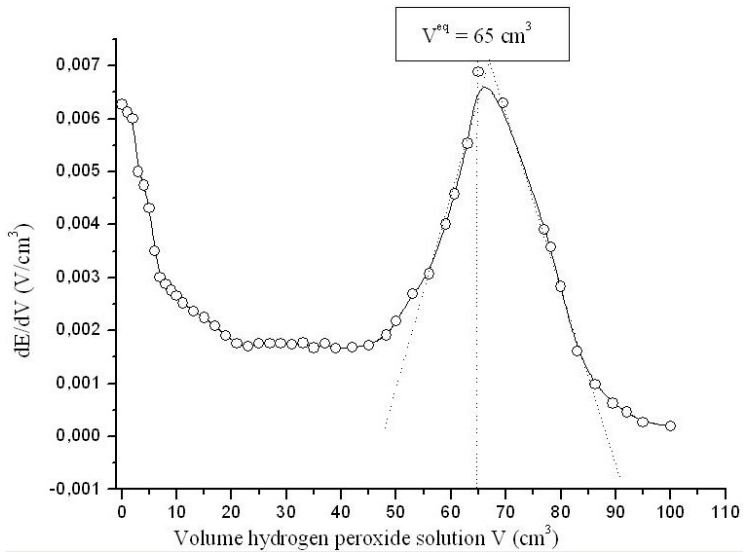

(b)

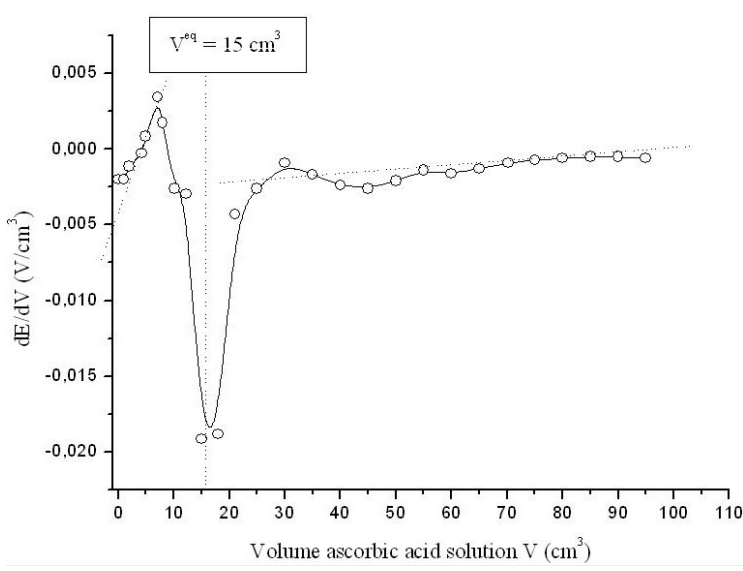

(d)

FIG. 1. (a,b) - Titration of $30 \mathrm{~cm}^{3}$ of ascorbic acid solution $\left(C=0.05 \mathrm{~mole} / \mathrm{dm}^{3}\right)$ by the hydrogen peroxide solution $\left(C=0.025\right.$ mole $\left./ \mathrm{dm}^{3}\right)$ in $30 \mathrm{~cm}^{3}$ of acetic buffer $\mathrm{CH}_{3} \mathrm{COOH} / \mathrm{CH}_{3} \mathrm{COONa}$ $(1 / 1)$ - integral (a) and differential (b) curves. (c,d) - Titration of $30 \mathrm{~cm}^{3}$ of hydrogen peroxide solution $\left(C=0.025 \mathrm{~mole} / \mathrm{dm}^{3}\right)$ by ascorbic acid solution $\left(C=0.05 \mathrm{~mole} / \mathrm{dm}^{3}\right)$ in $20 \mathrm{~cm}^{3}$ of acetic buffer $\mathrm{CH}_{3} \mathrm{COOH} / \mathrm{CH}_{3} \mathrm{COONa}(1 / 1)$ - integral (c) and differential (d) curves. $E$ is potential of $\mathrm{Pt}$ electrode relative normal calomel electrode

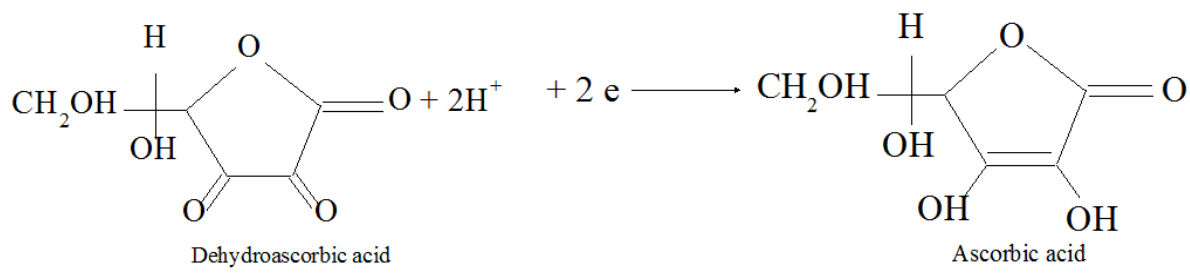

The full oxidation-reduction reaction is given by reaction (3.1). It is the difference between semi-reactions (6.1) and (6.3). Full oxidation-reduction reaction is given by reaction (3.2): $I$ is the difference between semi-reactions (6.2) and (6.3).

Differences of electromotive forces in plateaus in Figs. 1(a,c) and 2(a,c) are, correspondingly:

$$
\Delta E_{3.1} \approx 0.32-0.03 \approx 0.29 \mathrm{~V} ; \quad \Delta E_{3.2} \approx 0.34-0.03 \approx 0.31 \mathrm{~V}
$$




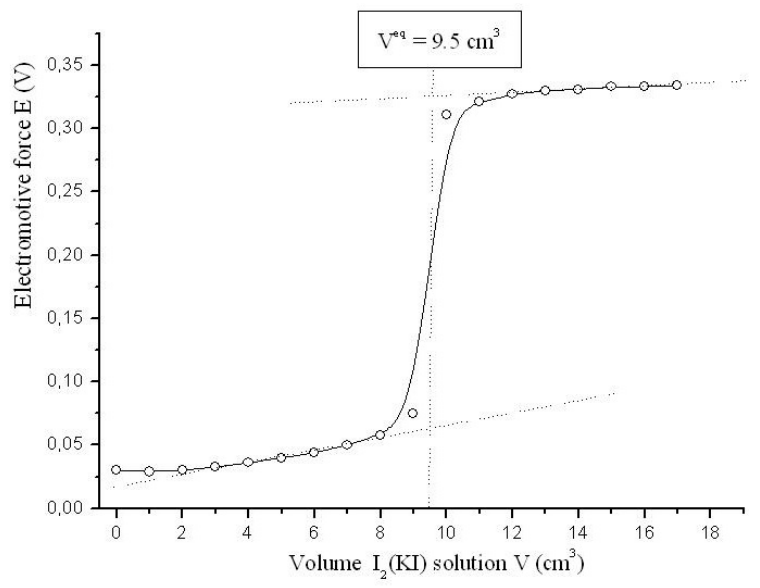

(a)

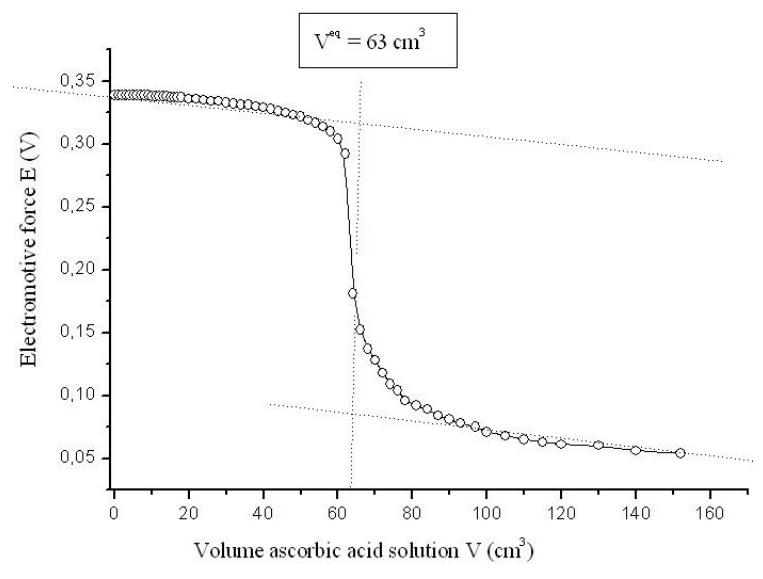

(c)

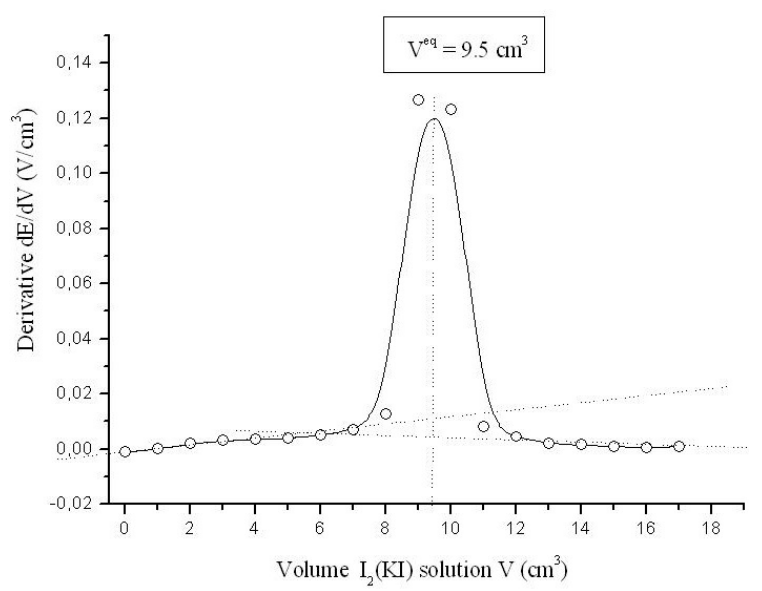

(b)

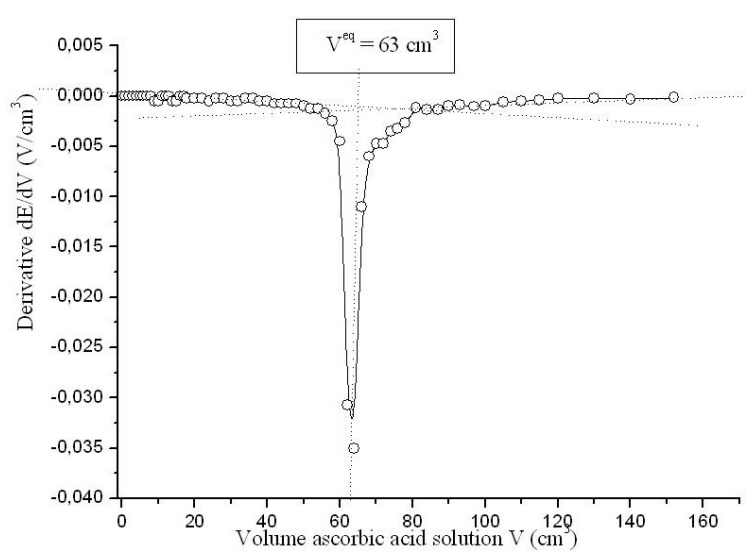

(d)

FIG. 2. (a,b) - Titration of $25 \mathrm{~cm}^{3}$ of ascorbic acid solution $\left(C=0.025 \mathrm{~mole} / \mathrm{dm}^{3}\right)$ by $\mathrm{I}_{2}$ (in $\mathrm{KI}$ ) solution $\left(C=0.05 \mathrm{~mole} / \mathrm{dm}^{3}\right)$ in $20 \mathrm{~cm}^{3}$ of acetic buffer $\mathrm{CH}_{3} \mathrm{COOH} / \mathrm{CH}_{3} \mathrm{COONa}$ $(1 / 1)$ - integral (a) and differential (b) curves. (c,d) - Titration of $30 \mathrm{~cm}^{3}$ of $\mathrm{I}_{2}$ (in KI) solution $\left(C=0.05 \mathrm{~mole} / \mathrm{dm}^{3}\right)$ by ascorbic acid solution $\left(C=0.025 \mathrm{~mole} / \mathrm{dm}^{3}\right)$ in $20 \mathrm{~cm}^{3}$ of acetic buffer $\mathrm{CH}_{3} \mathrm{COOH} / \mathrm{CH}_{3} \mathrm{COONa}(1 / 1)$ - integral (c) and differential (d) curves. $E$ is potential of $\mathrm{Pt}$ electrode relative normal calomel electrode

So, change of Gibbs potential of the oxidation ascorbic acid reactions (3.1) and (3.2), correspondingly in forward directions is:

$$
\Delta G_{3.1} \approx-56.0 \mathrm{~kJ} / \mathrm{mole} ; \quad \Delta G_{3.2} \approx-59.8 \mathrm{~kJ} / \mathrm{mole},
$$

and equilibrium constant $\left(K_{e q}\right)$ of both these reactions (at normal conditions) are sufficiently large: $\ln \left[K_{e q}\right]=$ $22-24$ rel.un.; $K_{e q-3.1}=3.6 \cdot 10^{9}, K_{e q-3.2}=2.6 \cdot 10^{10}$, and both reactions are practically irreversible. It is also proved by the form of titration curves Figs. 1(a-d) and 2(a-d).

\subsection{Titration of fullerenol-d by hydrogen peroxide and molecular $I_{2}$ and vice versa}

To investigate antioxidant properties of fullerenol-d acid we determined redox potential Ehat fixed value of hydrogen indicator $p H=4.77$, which was set by acetate buffer solution $\mathrm{CH}_{3} \mathrm{COOH} / \mathrm{CH}_{3} \mathrm{COONa}$ (molar relation 
1/1). We used following electrochemical cells (see earlier):

$$
\mathrm{Hg}, \mathrm{Hg}_{2} \mathrm{Cl}_{2} / \mathrm{KCl}\left(1 \mathrm{~mole} / \mathrm{dm}^{3}\right) / \text { investigated solution/Pt (compact), }
$$

where: $\mathrm{Pt}$ (compact) is working electrode; $\mathrm{Hg}, \mathrm{Hg}_{2} \mathrm{Cl}_{2} / \mathrm{KCl}$ - reference normal calomel electrode with constant potential $E^{0}=0.281 \mathrm{~V}$ [58]. Investigated solution in had two compositions:

$$
\begin{aligned}
& \text { /fullerenol-d + oxy - fullerenol-d }+\mathrm{H}_{2} \mathrm{O}_{2}+\mathrm{O}_{2}+\mathrm{H}^{+} \text {(acetate buffer) } / \text {; } \\
& \text { /fullerenol-d }+ \text { oxy - fullerenol-d }+\mathrm{I}_{2}+\mathrm{I}^{-}(\mathrm{KI})+\mathrm{H}^{+} \text {(acetate buffer) } / \text {. }
\end{aligned}
$$

The integral and differential curves of the titration of $\mathrm{H}_{2} \mathrm{O}_{2}$ by fullerenol-d and vice-versa fullerenol-d by $\mathrm{H}_{2} \mathrm{O}_{2}$ are represented in Fig. 3(a-d).

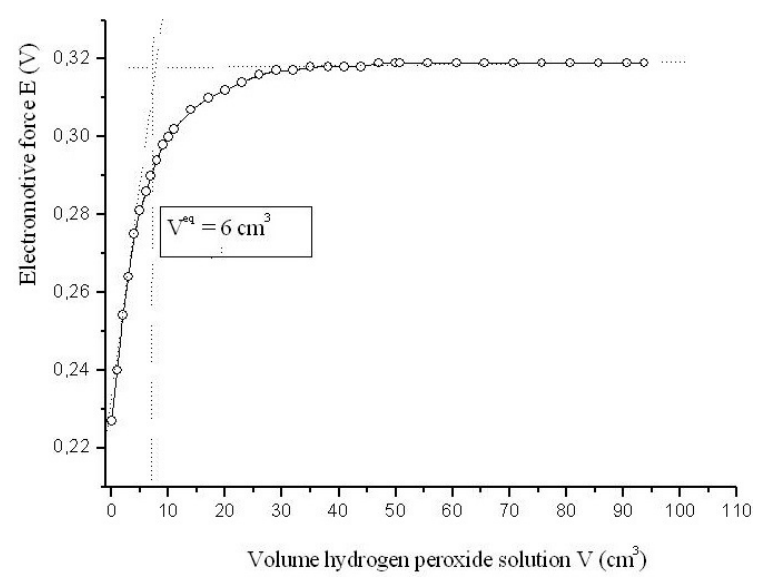

(a)

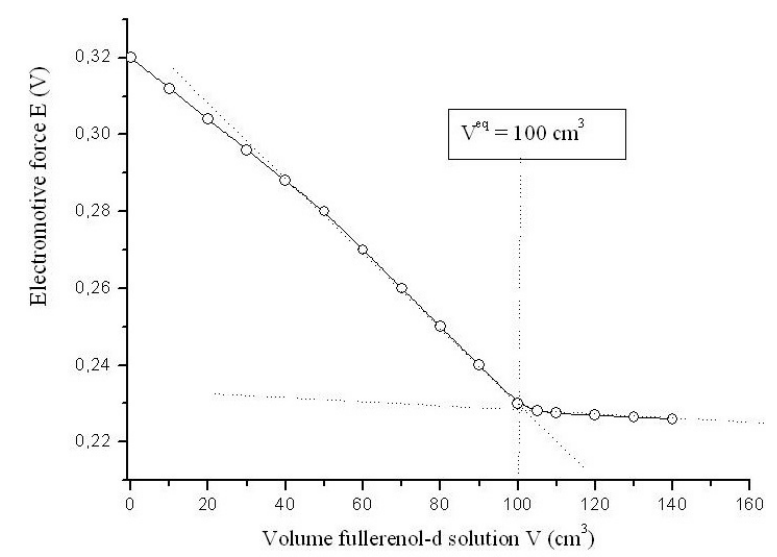

(c)

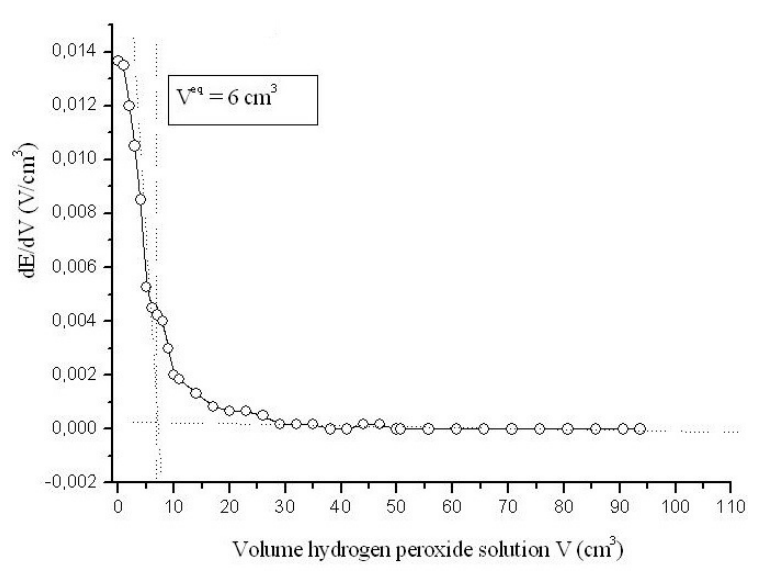

(b)

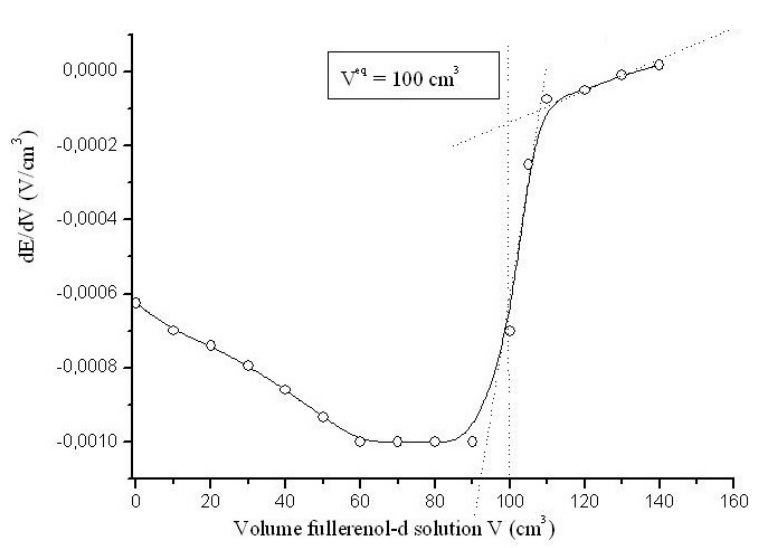

(d)

FIG. 3. (a,b) - Titration of $25 \mathrm{~cm}^{3}$ fullerenol-d solution $\left(C=0.005 \mathrm{~mole} / \mathrm{dm}^{3}\right)$ by the hydrogen peroxide solution $\left(C=0.020 \mathrm{~mole} / \mathrm{dm}^{3}\right)$ in $20 \mathrm{~cm}^{3}$ of acetic buffer $\mathrm{CH}_{3} \mathrm{COOH} / \mathrm{CH}_{3} \mathrm{COONa}$ $(1 / 1)$ - integral (a) and differential (b) curves. (c,d) - Titration of $25 \mathrm{~cm}^{3}$ hydrogen peroxide solution $\left(C=0.020 \mathrm{~mole} / \mathrm{dm}^{3}\right)$ by fullerenol-d solution $\left(C=0.005 \mathrm{~mole} / \mathrm{dm}^{3}\right)$ in $20 \mathrm{~cm}^{3}$ of acetic buffer $\mathrm{CH}_{3} \mathrm{COOH} / \mathrm{CH}_{3} \mathrm{COONa}(1 / 1)$ - integral (c) and differential (d) curves. $E$ is potential of $\mathrm{Pt}$ electrode relative normal calomel electrode

The integral and differential curves of the titration of $\mathrm{I}_{2}$ (in KI) by fullerenol-d and vice-versa fullerenol-d by $\mathrm{I}_{2}$ (in KI) are represented in Fig. 4(a-d). 


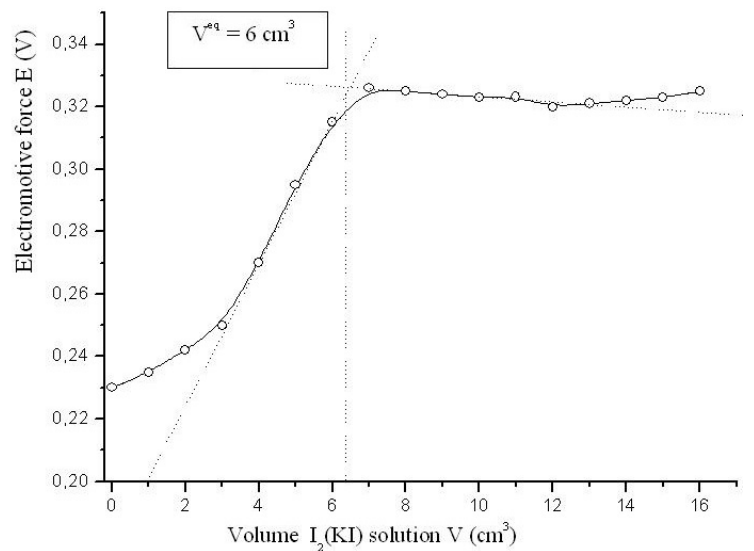

(a)

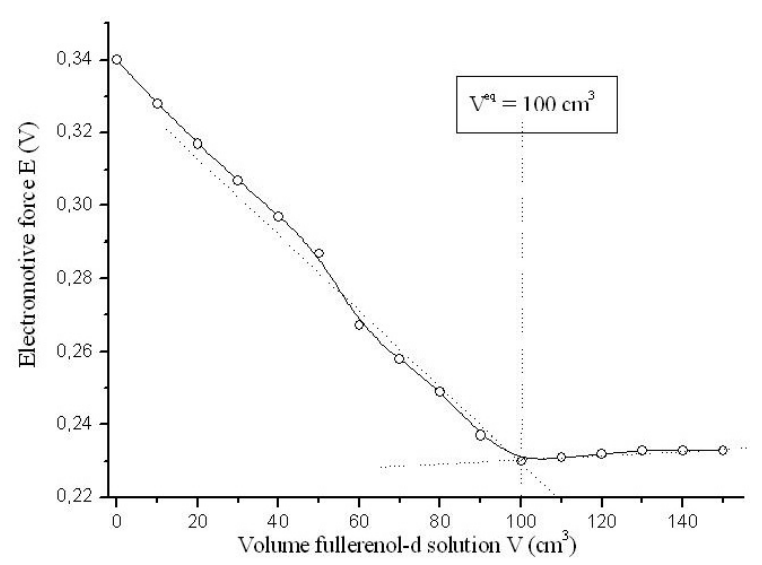

(c)

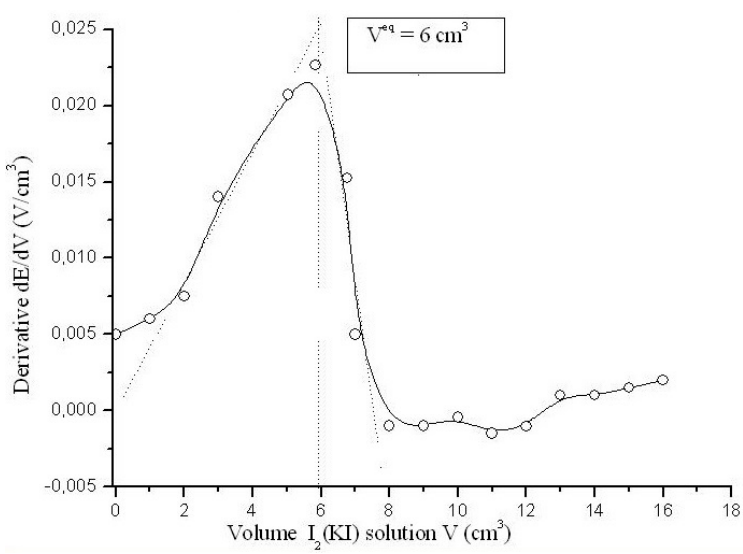

(b)

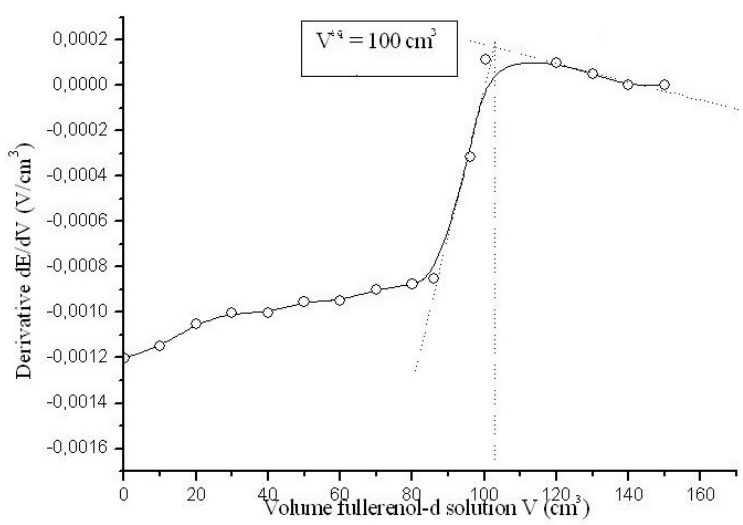

(d)

FIG. 4. (a,b) - Titration of $25 \mathrm{~cm}^{3}$ fullerenol-d solution $\left(C=0.005 \mathrm{~mole} / \mathrm{dm}^{3}\right)$ by $\mathrm{I}_{2}$ (in $\mathrm{KI}$ ) solution $\left(C=0.020 \mathrm{~mole} / \mathrm{dm}^{3}\right)$ in $20 \mathrm{~cm}^{3}$ of acetic buffer $\mathrm{CH}_{3} \mathrm{COOH} / \mathrm{CH}_{3} \mathrm{COONa}(1 / 1)-$ integral (a) and differential (c) curves. (c,d) - Titration of $25 \mathrm{~cm}^{3}$ of $\mathrm{I}_{2}$ (in $\mathrm{KI}$ ) solution $(C=$ $\left.0.020 \mathrm{~mole} / \mathrm{dm}^{3}\right)$ by fullerenol-d solution $\left(C=0.005 \mathrm{~mole} / \mathrm{dm}^{3}\right)$ in $20 \mathrm{~cm}^{3}$ of acetic buffer $\mathrm{CH}_{3} \mathrm{COOH} / \mathrm{CH}_{3} \mathrm{COONa}(1 / 1)$ - integral (c) and differential (d) curves. $E$ is potential of $\mathrm{Pt}$ electrode relative normal calomel electrode

One can see nearly equivalent quantities of fullerenol-d and hydrogen peroxide and $\mathrm{I}_{2}$ (KI), according to eq. (10):

$$
\mathrm{C}_{60}(\mathrm{OH})_{20-22} \mathrm{O}_{2}+2 \mathrm{H}^{+}+\overline{2} e \rightarrow \mathrm{C}_{60}(\mathrm{OH})_{22-24} \text {. }
$$

- Upper plateau $E_{1} \approx 0.32 \mathrm{~V}$ (Fig. 3(a)) and initial part of curve (Fig.3(c)) corresponds to the electrode semi-reaction (6.1): $\mathrm{O}_{2}+2 \mathrm{H}^{+\cdot}+2 \bar{e} \rightarrow \mathrm{H}_{2} \mathrm{O}_{2}(\mathrm{Pt})$ as earlier.

- Upper plateau $E_{2} \approx 0.34 V$ (Fig. 4(a)) and initial part of curve (Fig. 4(c)) corresponds to electrode semi-reaction (6.2): $\mathrm{I}_{2}$ (liquid) $+2 e \rightarrow 2 \mathrm{I}^{-}(\mathrm{Pt}$ ).

- Bottom plateau in four curves $E_{3} \approx 0.23 V$ (Figs. 3(a,c), 4(a,c) corresponds to the same electrode semireaction (10).

Full oxidation-reduction reactions in electrochemical cell are:

$$
\begin{gathered}
\mathrm{C}_{60}(\mathrm{OH})_{22-24}+\mathrm{O}_{2}=\mathrm{C}_{60}(\mathrm{OH})_{20-22} \mathrm{O}_{2}+\mathrm{H}_{2} \mathrm{O}_{2}, \\
\mathrm{C}_{60}(\mathrm{OH})_{22-24}+\mathrm{I}_{2}=\mathrm{C}_{60}(\mathrm{OH})_{20-22} \mathrm{O}_{2}+2 \mathrm{HI} .
\end{gathered}
$$


Reaction (11.1) is the difference between semi-reaction (6.1) and (10), reaction (11.2) is the difference between semi-reaction (6.2) and (10).

Differences of electromotive forces in plateaus in Figs. 3(a,c) and 4(a,c) are, correspondingly:

$$
\Delta E_{3.1} \approx 0.32-0.23 \approx 0.09 \mathrm{~V} ; \quad \Delta E_{3.2} \approx 0.34-0.23 \approx 0.11 \mathrm{~V}
$$

So, change of Gibbs potential of the oxidation fullerenol-d reactions (11.1) and (11.2), correspondingly in forward directions is:

$$
\Delta G_{3.1} \approx-17.3 \mathrm{~kJ} / \mathrm{mole} ; \quad \Delta G_{3.2} \approx-21.2 \mathrm{~kJ} / \mathrm{mole},
$$

and equilibrium constant $\left(K_{e q}\right)$ of both these reactions (at normal conditions) are not so large (as in the case of ascorbic acid): $\ln \left[K_{e q}\right]=7.0-8.6$ rel.un.; $K_{e q-3.1}=1.1 \cdot 10^{3}, K_{e q-3.2}=5.4 \cdot 10^{3}$ rel.un. and both reactions are more or less reversible. It is also proved by the form of titration curves Figs. 3(a-d) and 4(a-d). One can see, that integral titration curves $(3.1,3.3,4.1,4.3)$ do not have sigmoid character. Differential curves $(3.2,3.4,4.2,4.4)$ meanwhile sometimes (with $\mathrm{I}_{2}(\mathrm{KI})$ as oxidant) keep extremal character, but considerably less expressed than in the case of ascorbic acid. The values of the derivatives modules $/ d E / d V\left(V / \mathrm{cm}^{3}\right) /$ in the case of ascorbic acid are considerably higher than in the case of fullerenol-d (compare extremal $/ d E / d V /$ values: $0.007,0.018,0.12$, $0.35 \mathrm{~V} / \mathrm{cm}^{3}$ (Figs. 1(b,d), 2(b,d)) in the first case and $/ d E / d V /$ values: absence, absence, 0.02, absence $\mathrm{V} / \mathrm{cm}^{3}$ (Figs. 3(b,d), 4(b,d)).

So, we can state, that:

- Fullerenol-d is more week antioxidant in the comparison with ascorbic acid, at least, in relation to free radicals, generated by hydrogen peroxide and iodine.

- Fullerenol-d, in the contrast with ascorbic acid, is capable to the reversible absorption of free radicals, other words fullerenol-d molecules are able to sorb free radical and then (after change of ox-red potential - Eh or hydrogen indicator $-p H$ ) are able to desorb these free radicals and recover. Such process can easily materialize at transition of modified fullerenes from the mouth to the stomach then to the intestines.

- As a consequence fullerenols-d molecules are able to multiply reversible absorption-desorption of some free radicals.

\subsection{Pourbaix diagrams hydrogen-oxygen and iodine forms}

We calculated Pourbaix Diagrams for hydrogen-oxygen and iodine forms, based on data from Tables 1, 2 [58]. Pourbaix Diagrams for hydroxy species and ascorbic acid are represented in Fig. 5 and for iodine forms and ascorbic acid - in Fig. 6. Green spots symbolize our experimental conditions, red curves - Pt electrode potential formation reactions in our experiment, moving along the spot occurs because the concentrations of oxidized and reduced species are changed in the titration processes.

\section{Conclusions}

The antioxidant properties of aqueous fullerenol-d solutions were investigated against free radicals, generated by hydrogen peroxide and molecular $\mathrm{I}_{2}(\mathrm{KI})$. Measurement of fullerenol antioxidant activity was based on potentiometric titration of fullerenol solutions by hydrogen peroxide and molecular $\mathrm{I}_{2}$ (KI) solutions and vice versa with compact Pt as working electrode. Ascorbic acid, a common and strong antioxidant - was utilized as a comparative agent. Pourbaix Diagrams $(p H-E h)$ for hydrogen-oxygen and iodine forms were constructed. Fullerenol-d is a weaker antioxidant in comparison to ascorbic acid, but in contrast, fullerenols-d molecules are able to undergo multiply reversible absorption-desorption of some free radicals.

\section{Acknowledgements}

This work was supported by Russian Foundation of Basic Research - RFBR (Projects No. 16-08-01206, 18-08-00143) and Russian Found of the Support of Small Business (Project No. 24357). 
TABLE 1. Oxygen-hydrogen oxidation-reduction reactions (water solutions, $T=298 \mathrm{~K}$ )

\begin{tabular}{|c|c|c|}
\hline $\begin{array}{l}\text { Reaction } \\
\text { (field number of oxidized form// } \\
\text { field number of reduced form) } \\
\text { in Pourbaix diagrams (Fig. 5) }\end{array}$ & Nernst Equation & $\begin{array}{l}\text { Standard } \\
\text { Electro- } \\
\text { Motive } \\
\text { Force- } \\
E^{0}(\mathrm{~V})\end{array}$ \\
\hline $\begin{array}{c}\mathrm{O}:+2 \mathrm{H}^{+}+2 \bar{e} \rightarrow \mathrm{H}_{2} \mathrm{O}(\mathrm{Pt}) \\
\mathrm{I} / \mathrm{II}\end{array}$ & $\begin{array}{c}E=E^{0}+R T / 2 F \ln \left[a_{O}: a_{H^{+}}^{2} / a_{H_{2} O}\right]= \\
E^{0}-0.059 p H+0.295 \lg \left[a_{O:} / a_{H_{2} O}\right]\end{array}$ & 2.422 \\
\hline $\begin{array}{c}\mathrm{O}_{3}+2 \mathrm{H}^{+}+2 \bar{e} \rightarrow \mathrm{O}_{2}+\mathrm{H}_{2} \mathrm{O}(\mathrm{Pt}) \\
\text { III/IV }\end{array}$ & $\begin{array}{c}E=E^{0}+R T / 2 F \ln \left[a_{\mathrm{O}_{3}} a_{H^{+}}^{2} / a_{\mathrm{H}_{2} \mathrm{O}} P_{\mathrm{O}_{2}}\right]= \\
E^{0}-0.059 p H+0.295 \lg \left[a_{\mathrm{O}_{3}} / a_{\mathrm{H}_{2} \mathrm{O}} P_{\mathrm{O}_{2}}\right]\end{array}$ & 2.070 \\
\hline $\begin{array}{c}\mathrm{OH}^{-}+\underset{\mathrm{V} / / \mathrm{VI}}{\operatorname{\mathrm {OH}^{-}}(\mathrm{Pt})} \\
\end{array}$ & $\begin{array}{c}E=E^{0}+R T / F \ln \left[a_{O H} / a_{O H^{-}}\right]= \\
E^{0}+0.059(14-p H)+0.059 \lg a_{O H}= \\
E^{0}+0.826-0.059 p H+0.059 \lg a_{O H}\end{array}$ & 2.020 \\
\hline $\begin{array}{c}\mathrm{H}_{2} \mathrm{O}_{2}+2 \mathrm{H}^{+}+2 \bar{e} \rightarrow 2 \mathrm{H}_{2} \mathrm{O}(\mathrm{Pt}) \\
\text { VII/II }\end{array}$ & $\begin{array}{c}E=E^{0}+R T / 2 F \ln \left[a_{\mathrm{H}_{2} \mathrm{O}_{2}} a_{\mathrm{H}^{+}}^{2} / a_{\mathrm{H}_{2} \mathrm{O}}^{2}\right]= \\
E^{0}-0.059 p H+0.0295 \lg \left[a_{\mathrm{H}_{2} \mathrm{O}_{2}} a_{\mathrm{H}^{+}}^{2} / a_{\mathrm{H}_{2} \mathrm{O}}^{2}\right]\end{array}$ & 1.776 \\
\hline $\begin{array}{c}\mathrm{O}_{3}+\mathrm{H}_{2} \mathrm{O}+2 \bar{e} \rightarrow \mathrm{O}_{2} \\
\text { VIII } / / \mathrm{IX}\end{array}$ & $\begin{array}{c}E=E^{0}+R T / 2 F \ln \left[a_{O_{3}} a_{H_{2} O} / a_{\mathrm{OH}^{-}}^{2} P_{\mathrm{O}_{2}}\right]= \\
E^{0}+0.059(14-p H)+0.0295 \lg \left[a_{\mathrm{O}_{3}} a_{\mathrm{H}_{2} \mathrm{O}} / P_{\mathrm{O}_{2}}\right]= \\
E^{0}+0.826-0.059 p H+0.295 \lg \left[a_{O_{3}} / a_{\mathrm{H}_{2} O} P_{\mathrm{O}_{2}}\right]\end{array}$ & 1.240 \\
\hline $\begin{array}{c}\mathrm{O}_{2}+4 \mathrm{H}^{+\cdot}+4 \bar{e} \rightarrow 2 \mathrm{H}_{2} \mathrm{O}(\mathrm{Pt}) \\
\mathrm{X} / \mathrm{II}\end{array}$ & $\begin{array}{l}E=E^{0}+R T / 4 F \ln \left[P_{\mathrm{O}_{2}} a_{\mathrm{H}^{+}}^{4} / a_{\mathrm{H}_{2} \mathrm{O}}^{2}\right]= \\
E^{0}-0.059 p H+0.01475 \lg \left[P_{\mathrm{O}_{2}} / a_{\mathrm{H}_{2} \mathrm{O}}^{2}\right]\end{array}$ & 1.229 \\
\hline $\begin{array}{c}\mathrm{O}_{2}(g)+2 \mathrm{H}^{+}(\mathrm{Pt})+\overline{2} e \\
\text { XI//XII }\end{array}$ & $\begin{aligned} E & =E^{0}+R T / 2 F \ln \left[P_{\mathrm{O}_{2}} / a\left(H^{+}\right)^{2} / P_{\mathrm{H}_{2} \mathrm{O}_{2}}\right] \\
E^{0} & -0.059 p H+0.0295 \lg \left[P_{\mathrm{O}_{2}} / X_{\mathrm{H}_{2} \mathrm{O}_{2}} K_{\mathrm{H}_{2} \mathrm{O}_{2}}^{H}\right]\end{aligned}$ & 0.839 \\
\hline $\begin{array}{c}\mathrm{C}_{60}(\mathrm{OH})_{20 \div 22} \mathrm{O}_{2}+2 \mathrm{H}^{+}+2 \bar{e} \rightarrow \mathrm{C}_{60}(\mathrm{OH})_{22 \div 24} \\
\text { XIII//XIV }\end{array}$ & $\begin{array}{c}E=E^{0}-0.059 p H+ \\
0.0295 \lg \left(a_{\text {oxy-fullerenol-d }} / a_{\text {fullerenol-d }}\right)\end{array}$ & 0.797 \\
\hline $\begin{array}{c}\mathrm{O}_{2}+2^{+\cdot}+2 \bar{e} \rightarrow \mathrm{H}_{2} \mathrm{O}_{2}(l)(\mathrm{Pt}) \\
\text { XV/XVI }\end{array}$ & $\begin{array}{c}E=E^{0}+R T / 2 F \ln \left[P_{\mathrm{O}_{2}} a_{H^{+}}^{2} / a_{\mathrm{H}_{2} \mathrm{O}_{2}}\right]= \\
E^{0}-0.059 p H+0.0295 \lg \left[P_{\mathrm{O}_{2}} / a_{\mathrm{H}_{2} \mathrm{O}_{2}}\right]\end{array}$ & 0.682 \\
\hline $\begin{array}{c}\text { dehydroascorbic(acid) }+2 \mathrm{H}^{+}+ \\
2 \bar{e} \rightarrow \text { ascorbic(acid) } \\
\text { XVII//XVIII }\end{array}$ & $\begin{array}{c}E=E^{0}-0.059 p H+ \\
0.0295 \lg \left(a_{\text {dehydroascorbic(acid) }} / a_{\text {ascorbic(acid) }}\right)\end{array}$ & 0.613 \\
\hline $\begin{array}{c}1 / 2 \mathrm{O}_{2}+2 \mathrm{H}_{2} \mathrm{O}+2 \bar{e} \\
\mathrm{XIX} / \mathrm{VI}\end{array}$ & $\begin{array}{c}E=E^{0}+R T / 2 F \ln \left[P_{\mathrm{O}_{2}}^{1 / 2} a_{\mathrm{H}_{2} \mathrm{O}}^{2} / a_{\mathrm{OH}^{-}}^{2}\right]= \\
E^{0}+0.059(14-p H)+0.0295 \lg \left[P_{\mathrm{O}_{2}}^{1 / 2} a_{\mathrm{H}_{2} \mathrm{O}}^{2}\right]= \\
E^{0}+0.826-0.059 p H+0.0295 \lg \left[P_{\mathrm{O}_{2}}^{1 / 2} a_{\mathrm{H}_{2} \mathrm{O}}^{2}\right]\end{array}$ & 0.401 \\
\hline $\begin{array}{c}\mathrm{H}^{+\cdot}+\bar{e} \rightarrow 1 / 2 \mathrm{H}_{2}(\mathrm{Pt}) \\
\quad \mathrm{XX} / / \mathrm{XXI} \\
\end{array}$ & $\begin{array}{c}E=E^{0}+R T / F \ln \left[a_{H^{+}} / P_{H_{2}}^{1 / 2}\right]= \\
E^{0}-0.059 p H-0.0295 \lg \left[P_{H_{2}}\right]\end{array}$ & 0.000 \\
\hline $\begin{array}{c}2 \mathrm{H}_{2} \mathrm{O}+2 \bar{e} \rightarrow \mathrm{H}^{-}+2 \mathrm{OH}^{-}(\mathrm{Pt}) \\
\text { XXII/ } / \mathrm{XXIII}\end{array}$ & $\begin{array}{c}E=E^{0}+R T / 2 F \ln \left[a_{\mathrm{H}_{2} \mathrm{O}}^{2} / a_{H^{\cdot}} \cdot a_{\mathrm{OH}^{-}}^{2}\right]= \\
E^{0}+0.059(14-p H)+0.0295 \lg \left[a_{\mathrm{H}_{2} \mathrm{O}}^{2} / a_{H^{\cdot}}\right]= \\
E^{0}+0.826-0.059 p H+0.0295 \lg \left[a_{\mathrm{H}_{2} \mathrm{O}}^{2} / a_{H^{\cdot}}\right]\end{array}$ & -0.828 \\
\hline
\end{tabular}

Where: $\mathrm{K}_{\mathrm{H}_{2} \mathrm{O}_{2}}^{\mathrm{H}}, \mathrm{X}\left(\mathrm{H}_{2} \mathrm{O}_{2}\right)$ - Henry constant and molar fraction of $\mathrm{H}_{2} \mathrm{O}_{2}$ in liquid phase, (l) and (g) - liquid and gaseous phase states of component; $a_{i}, p_{i}$ - activity and partial pressure (atm.) of $i$-th component. 
TABLE 2. Iodine oxidation-reduction reactions (water solutions, $T=298 \mathrm{~K}$ )

\begin{tabular}{|c|c|c|}
\hline $\begin{array}{c}\text { Reaction } \\
\text { (field number of oxidized form// } \\
\text { field number of reduced form) } \\
\text { in Pourbaix diagrams (Fig. 6) }\end{array}$ & Nernst Equation & $\begin{array}{c}\text { Standard } \\
\text { Electro- } \\
\text { Motive } \\
\text { Force }-E^{0}(\mathrm{~V})\end{array}$ \\
\hline 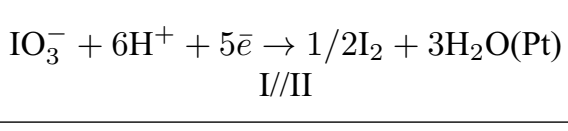 & $\begin{array}{l}E=E^{0}+R T / 5 F \ln \left[a_{I O_{3}^{-}} a_{H^{+}}^{6} / a_{I_{2}}^{1 / 2} a_{H_{2} O}^{3}\right]= \\
E^{0}+0.0118 \lg \left[a_{I O_{3}^{-}} / a_{I_{2}}^{1 / 2} a_{H_{2} O}^{3}\right]-0.0708 p H\end{array}$ & 1.195 \\
\hline $\begin{array}{c}\mathrm{C}_{60}(\mathrm{OH})_{20 \div 22} \mathrm{O}_{2}+2 \mathrm{H}^{+}+ \\
2 \bar{e} \rightarrow \mathrm{C}_{60}(\mathrm{OH})_{22 \div 24} \\
\text { III/IV }\end{array}$ & $\begin{array}{c}E=E^{0}-0.059 p H+ \\
0.0295 \lg \left(a_{\text {oxy-fullerenol-d }} / a_{\text {fullerenol-d }}\right)\end{array}$ & 0.797 \\
\hline $\begin{array}{c}1 / 2 \mathrm{I}_{2}(l)^{\cdot}+\bar{e} \rightarrow \mathrm{I}^{-}(\mathrm{Pt}) \\
\mathrm{IV} / \mathrm{V}\end{array}$ & $\begin{array}{c}E=E^{0}+R T / F \ln \left[a_{I_{2}}^{1 / 2} / a_{I^{-}}\right]= \\
E^{0}+0.059 \lg \left[a_{I_{2}}^{1 / 2} / a_{I^{-}}\right]\end{array}$ & 0.628 \\
\hline $\begin{array}{c}\text { dehydroascorbic(acid) }+2 \mathrm{H}^{+}+ \\
2 \bar{e} \rightarrow \operatorname{ascorbic}(\text { acid }) \\
\text { VI/VII }\end{array}$ & $\begin{array}{c}E=E^{0}-0.059 p H+ \\
0.0295 \lg \left(a_{\text {dehydroascorbic(acid) }} / a_{\text {ascorbic(acid) }}\right)\end{array}$ & 0.613 \\
\hline $\begin{array}{c}1 / 2 \mathrm{I}_{2}(c r)^{\cdot}+\bar{e} \rightarrow \mathrm{I}^{-}(\mathrm{Pt}) \\
\mathrm{VIII} / \mathrm{V}\end{array}$ & $\begin{array}{c}E=E^{0}+R T / F \ln \left[1 / a_{I^{-}}\right]= \\
E^{0}-0.059 \lg a_{I^{-}}\end{array}$ & 0.536 \\
\hline $\begin{array}{c}\mathrm{I}_{3}^{-\cdot}+2 \bar{e} \rightarrow 3 \mathrm{I}^{-}(\mathrm{Pt}) \\
\mathrm{IX} / \mathrm{V}\end{array}$ & $\begin{aligned} E= & E^{0}+R T / 2 F \ln \left[a_{I_{3}^{-}} / a_{I^{-}}^{3}\right]= \\
& E^{0}+0.0295 \lg \left[a_{I_{3}^{-}} / a_{I^{-}}^{3}\right]\end{aligned}$ & 0.536 \\
\hline
\end{tabular}

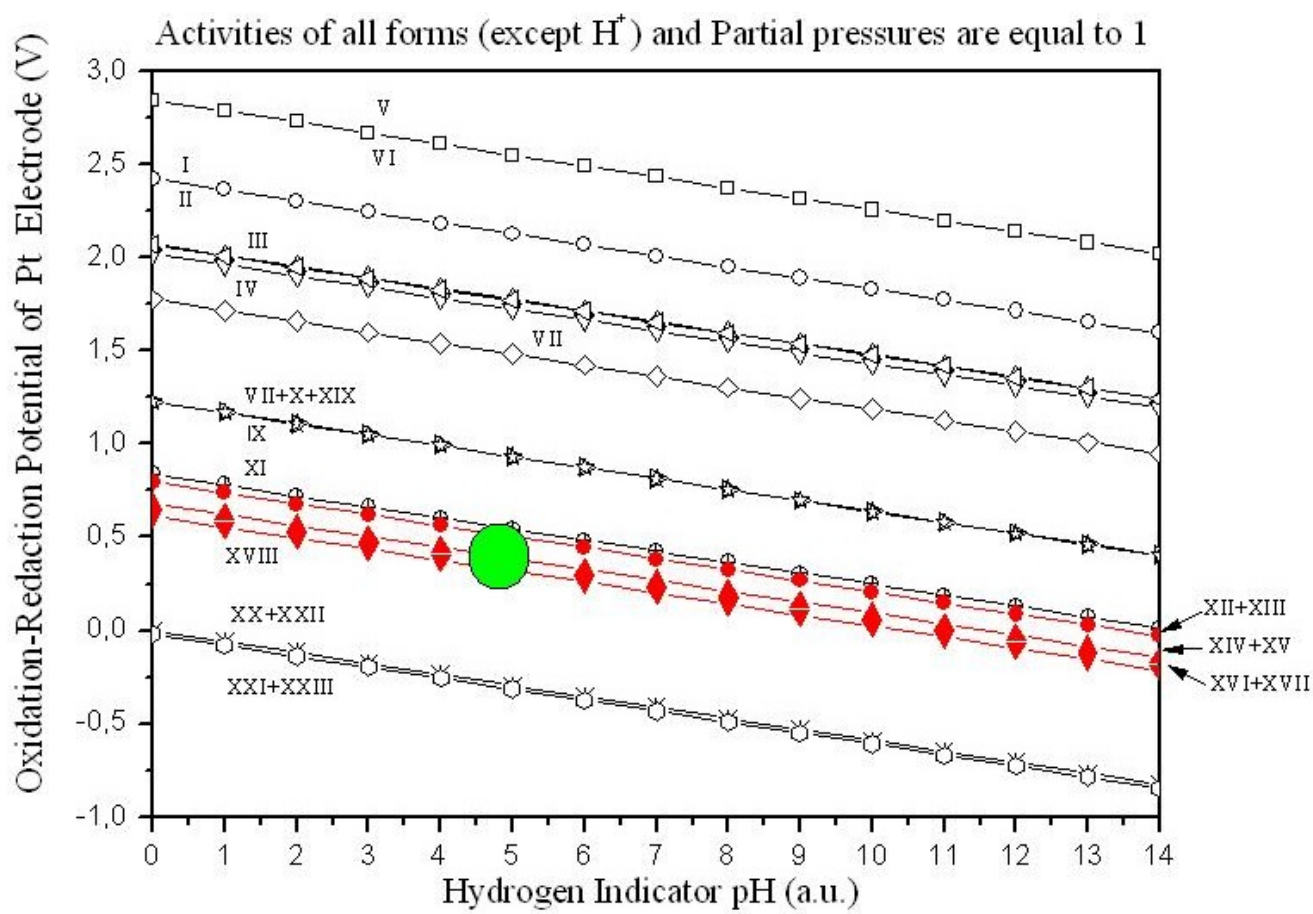

FIG. 5. Pourbaix Diagrams for hydrogen-oxygen forms and ascorbic acid (green spot symbolizes our experimental conditions, red curves - Pt electrode potential formation reactions in our experiment, moving along the spot occurs because oxidized and reduced forms concentrations are changed in the titration) 


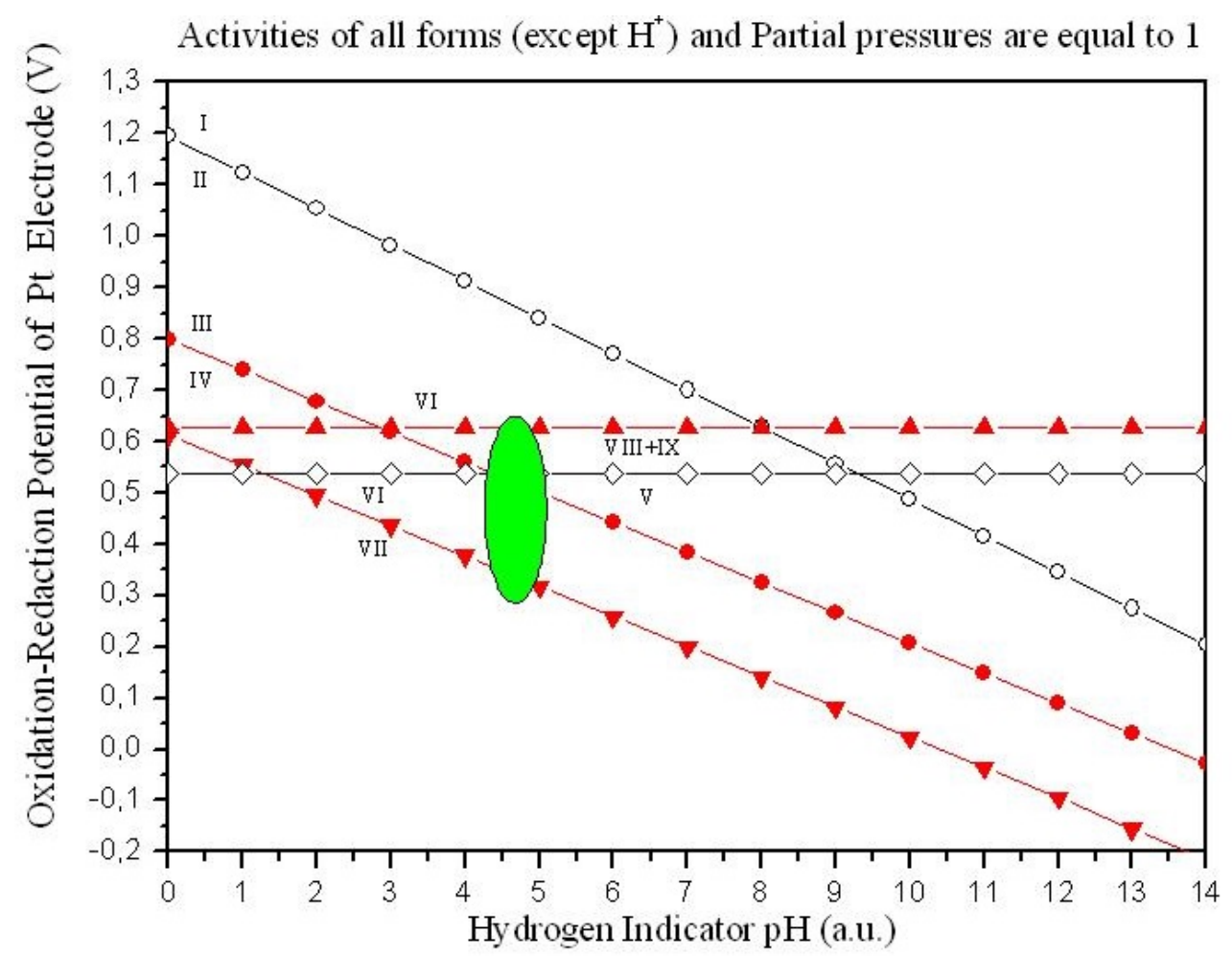

FIG. 6. Pourbaix Diagrams for iodine forms and ascorbic acid (green spot symbolizes our experimental conditions, red curves - Pt electrode potential formation reactions in our experiment, moving along the spot occurs because oxidized and reduced forms concentrations are changed in the titration)

\section{References}

[1] Li J., Takeuchi A., Ozawa M., et al. C60 Fullerol Formation catalysed by Quaternary Ammonium Hydroxides. J. Chem. Soc. Commun., 1993, 23, P. 1784-1785.

[2] Pinteala M., Dascalu A., Ungurenasu C. Binding fullerenol $\mathrm{C}_{60}(\mathrm{OH})_{24}$ to dsDNA. Int. J. Nanomedicine, 2009, 4, P. $193-199$.

[3] Chiang L.Y., Bhonsle J.B., et al. Efficient one-flask synthesis of water-soluble [60] fullerenols. Tetrahedron, 1996, 52, P. $4963-4672$.

[4] Chiang L.Y., Upasani R.B., Swirczewski J.W. Versatile nitronium chemistry for C60 fullerene functionalization. J. Am. Chem. Soc., 1992, 114, P. 10154-10157.

[5] Meier M.S., Kiegiel J. Preparation and characterization of thefullerene diols $1,2-\mathrm{C}_{60}(\mathrm{OH})_{2}, 1,2-\mathrm{C}_{70}(\mathrm{OH})_{2}$, and $5,6-\mathrm{C}_{70}(\mathrm{OH})_{2}$. Org. Lett., 2001, 3, P. 1717-1719.

[6] Szymanska L., Radecka H., Radecki J., Kikut-Ligaj D. Fullerene modified supported lipid membrane as sensitive element of sensor for odorants. Biosens. Bioelectron, 2001, 16, P. 911-915.

[7] Mirkov S.M., Djordjevic, A.N., et al. Nitric oxidescavenging activity of polyhydroxylated fullerenol, $\mathrm{C}_{60} \mathrm{OH}_{24}$. Nitric Oxide, 2004, 11, P. 201-207.

[8] Kokubo K., Matsubayashi K., et al. ACS Nano, 2008, 2, P. 327-333.

[9] Anderson R., Barron A.R. Reaction of hydroxyfullerene with metal salts: a route to remediation and immobilization. J. Am. Chem. Soc., 2005, 127 (30), P. 10458-10459.

[10] Kokubo K., Shirakawa S., et al. Facile and scalable synthesis of a highly hydroxylated water-soluble fullerenol as a single nanoparticle. Nano Research, 2011, 4 (2), P. 204-215.

[11] Yao L., Kang F., Peng Q., Yang X. An improved method for fullerol preparation based on dialysis. Chinese Journal of Chemical Engineering, 2010, 18 (5), P. 876-879.

[12] Huang H.-M., Ou H.-C., Hsieh S.-J., Chiang L.-Y. Blockage of amyloid beta peptide-induced cytosolic free calcium by fullerenol-1, carboxylate $\mathrm{C}_{60}$ in PC12 cells. Life Sciences, 2000, 66 (16), P. 1525-1533.

[13] Roberts J.E., Wielgus A.R., et al. Phototoxicity and cytotoxicity of fullerol in human lens epithelial cells. Toxicology and Applied Pharmacology, 2008, 228 (1), P. 49-58.

[14] Isakovic A., Markovic Z., Todorovic-Marcovic B., et al. Distinct cytotoxic mechanisms of pristine versus hydroxylated fullerene. Toxicological Sciences, 2006, 91 (1), P. 173-183.

[15] Johnson-Lyles D.N., Peifley K., Lockett S., et al. Fullerenol cytotoxicity in kidney cells is associated with cytoskeleton disruption, autophagic vacuole accumulation, and mitochondrial dysfunction. Toxicology and Applied Pharmacology, 2010, 248 (3), P. $249-258$.

[16] Wang S., He P., et al. Novel and efficient synthesis of water-soluble [60]fullerenol by solvent-free reaction. Synthetic Communications, 2005, 35 (13), P. 1803-1808.

[17] Piotrovskij L.B., Kiselev O.I. Fullerenes in biology. Rostok: Saint Petersburg, 2006. 
[18] Semenov K.N., Charykov N.A., Keskinov V.A. Fullerenol-70-d: Synthesis, identification, poly-thermal solubility and density of water solutions. Nanosystems: physics, chemistry, mathematics, 2012, 3 (6), P. 146-156.

[19] Assemi S., Tadjiki S., et al. Aggregation of fullerol $\mathrm{C}_{60}(\mathrm{OH})_{24}$ nanoparticles as revealed using flow field-flow fractionation and atomic force microscopy. Langmuir, 2010, 26 (20), P. 16063-16070.

[20] Vileno B., Marcoux P.R., et al. Spectroscopic and photophysical properties of a highly derivatized $\mathrm{C}_{60}$ fullerol. Advanced Functional Materials, 2006, 16 (1), P. 120-128.

[21] Schneider N.S., Darwish A.D., et al. Formation of fullerols via hydroboration of fullerene-C 60 . Journal of the Chemical Society, Chemical Communications, 1994, 4, P. 463-464.

[22] Semenov K.N., Charykov N.A., Letenko D.G., et al. Solubility and Some Properties of Aqueous Solutions of Fullerenol-d and Crystal Hydrates. Rus. J. of Appl. Chem., 2011, 84 (1), P. 44-49.

[23] Semenov K.N., Charykov N.A., Letenko D.G., et al. Electrochemical Properties of Aqueous Solutions of Fullerenol-d. Rus. J. of Appl. Chem., 2011, 84 (1), P. 79-83.

[24] Letenko D.G., Nikitin V.A., et al. Study of Aqueous Solutions of Fullerenol-d by the Dymamic Light Scattering Method. Rus. J. of Appl. Chem., 2011, 84 (1), P. 50-53.

[25] Ioutsi V., Sokolov S.A., Semivrazskhaya O.O., et al. Synthesis and antioxidative properties of some fullerene $\mathrm{C}_{60}$ derivatives. Reports RGMU. Medical biological problems, 2012, 5, P. 76-82.

[26] Zhang J.-M., Yang W., He P., Zhu S.-Z. Efficient and convenient preparation of water-soluble fullerenol. Chinese Journal of Chemistry, 2004, 22 (9), P. 1008-1011.

[27] Semenov K.N., Charykov N.A., Keskinov V.A. Fullerenol Synthesis and Identification. Properties of Fullerenol Water Solutions. J. Chem. Eng. Data, 2011, 56, P. 230-239.

[28] Semenov K.N., Charykov N.A., et al. The Synthesis and Identification of Mixed Fullerenol Prepared by the Direct One-Stage Oxidation of Fullerene Black. Rus. J. Phys. Chem., 2011, 85 (6), P. 1009-1015.

[29] Semenov K.N., Charykov N.A., Letenko D.G., et al. Synthesis and protecting action of fullerenol-d. II. Modification of water soluble priming enamel. Phys. Chem. of Surface and Metal Protection, 2012, 48 (3), P. 286-292.

[30] Letenko D.G., Nikitin V.A., et al. Conductivity of Aqueos Solutions of Fullerol Synthesized by Direct Oxidation. Rus. J. Phys. Chem., 2012, 86 (12), P. 1806-1813.

[31] Semenov K.N., Charykov N.A. Solubility Diagram of a Fullerenol- $\mathrm{dNaClH}_{2} \mathrm{O}$ System at 25 C. Rus. J. Phys. Chem., 2012, 86 (10), P. $1636-1639$.

[32] Semenov K.N., Charykov N.A., et al. Synthesis of Fullerenol-70-d by Direct Oxidation and Its Identification. Rus. J. Of Gen. Chem., 2013,83 (4), P. 674-678.

[33] Semenov K.N., Kanterman I.G., et al. SolidLiquid Phase Equilibria in the Fullerenol-- $\mathrm{dCuCl}_{2} \mathrm{H}_{2} \mathrm{O}$ System at 25 C. Russian Journal of Physical Chemistry, 2014, 88 (6), P. 1073-1076.

[34] Semenov K.N., Kanterman I.G., Charykov N.A., et al. Solubility in ternary system fullerenol-d-uranil sulphate-water at 25 . Radiochemistry, 2014, 56 (5), P. 421-422. (In Russian)

[35] Zolotarev A.A., Lushin A.I., et al. Impact resistance of cement and gypsum plaster nanomodified by water-soluble fullerenols. Industrial and engineering chemical research, 2013, 52, P. 14583-14591.

[36] Semenov K.N., Keskinov V.A., et al. The fullerenol-d solubility in the fullerenol-d-inorganic salt-water ternary systems at 250C. Industrial and engineering chemical research, 2013, 52, P. 16095-16100.

[37] Semenov K.N., Kanterman I.G., et al. SolidLiquid Phase Equilibria in the Fullerenol-d-CuCl $\mathrm{Cu}_{2}-\mathrm{H}_{2} \mathrm{O}$ System at 25 C. Russian Journal of Physical Chemistry, 2014, 88 (6), P. 1073-1076.

[38] Semenov K.N., Charykov N.A., Murin I.V., Pukharenko Yu.V. Physico-chemical properties of the fullerenol-70 water solutions. J. of Molecular Liquids, 2015, 202, P. 1-8.

[39] Tyurin D.P., Semenov K.N., et al. Dissociation of Fullerenol-70-d in Aqueous Solutions and Their Electric Conductivity. Russian Journal of Physical Chemistry A, 2015, 89 (5), P. 771-775.

[40] Panova G.G., Ktitorova I.N., et al. Impact of polyhydroxy fullerene (fullerol or fullerenol) on growth and biophysical characteristics of barley seedlings in favourable and stressful conditions. Plant Growth Regulation. An International Journal on Plant Growth and Development, 2015, 77 2016, 79 (3), P. 309-318.

[41] Charykov N.A., Semenov K.N., et al. Excess thermodynamic functions in aqueous systems containing soluble fullerene derivatives. $J$. of Molecular Liquids, 2018, 256, P. 305-311.

[42] Djordjevic A., Srdjenovic B., et al. Review of Synthesis and Antioxidant Potential of Fullerenol Nanoparticles. Journal of Nanomaterials, 2015, 567073, 15 pp.

[43] Lao F., Chen L., Li W., et al. Fullerene nanoparticles selectively enter oxidation-damaged cerebral microvessel endothelial cells and inhibit JNK-related apoptosis. ACS Nano, 2009, 3 (11), P. 3358-3368.

[44] Yin J.-J., Lao F., Fu P.P., et al. The scavenging of reactive oxygen species and the potential for cell protection by functionalized fullerene materials. Biomaterials, 2009, 30 (4), P. 611-621.

[45] Caputo F., De Nicola M., Ghibelli L. Pharmacological potential of bioactive engineered nanomaterials. Biochemical Pharmacology, 2014, 92 (1), P. 112-130.

[46] Djordjevic A., Canadanovic-Brunet J.M., Vojinovic-Miloradov M., Bogdanovic G. Antioxidant properties and hypothetic radical mechanism of fullerenol $\mathrm{C}_{60}(\mathrm{OH})_{24}$. Oxidation Communications, 2004, 27 (4), P. 806-812.

[47] Kokubo K. Water-Soluble Single-Nano Carbon Particles: Fullerenol and Its Derivatives, InTech, 2012.

[48] Kato S., Aoshima H., Saitoh Y., Miwa N. Highly hydroxylated or -cyclodextrin-bicapped water-soluble derivative of fullerene: the antioxidant ability assessed by electron spin resonance method and -carotene bleaching assay. Bioorganic and Medicinal Chemistry Letters, 2009, 19 (18), P. 5293-5296.

[49] Ueno H., Yamakura S., et al. Systematic evaluation and mechanistic investigation of antioxidant activity of fullerenols using carotene bleaching assay-carotene bleaching assay. Journal of Nanomaterials, 2014, 2014, 802596, 7 pp.

[50] Dordević A., Bogdanović G. Fullerenol: a new nanopharmaceutic? Archive of Oncology, 2008, 16 (3-4), P. $42-45$. 
[51] Pickering K.D., Wiesner M.R. Fullerol-sensitized production of reactive oxygen species in aqueous solution. Environmental Science and Technology, 2005, 39 (5), P. 1359-1365.

[52] Zhao B., Bilski P.J., et al. Photo-induced reactive oxygen species generation by different water-soluble fullerenes $\left(\mathrm{C}_{60}\right)$ and their cytotoxicity in human keratinocytes. Photochemistry and Photobiology, 2008, 84 (5), P. 1215-1223.

[53] Zhao B., He Y.-Y., et al. Difference in phototoxicity of cyclodextrin complexed fullerene $\left[(\gamma-\mathrm{CyD})_{2} / \mathrm{C}_{60}\right]$ and its aggregated derivatives toward human lens epithelial cells. Chemical Research in Toxicology, 2009, 22 (4), P. 660-667.

[54] Pourbaix M. Thermodynamics and corrosion. Corrosion Science, 1990, 3 (1), No. 10, P. 963-988.

[55] Remi G. Course of Inorganic Chemistry, volume 2. Moscow, Mir, 1955. (In Russian)

[56] Ball E.G. Studies on oxidation reduction. XXIII. Ascorbic acid. J. Biol. Chem., 1939, 118, P. $219-239$.

[57] Borsook H., Davenport H.W., et al. The Oxidation of Ascorbic Acid and Its in Vitro and in Vivo. J. Biol. Chem., 1937, 117, (1), P. 237-279.

[58] Brief reference book of physical and chemical quantities. Ed.: A.A. Ravdel, A.M. Ponomareva. Moscow, OOO TID Az-book, 2009, $237 \mathrm{pp}$. 